\title{
Nutrient Uptake and Soil Fertility Status as Influenced by Planting Geometry in Dolichos Bean
}

\author{
Samapika Dalai*, Shashikanth Evoor, R. Mulge, A.B. Mastiholi, \\ C.N. Hanchinamani, L. Kukanoor and V. Kantharaju \\ Department of Vegetable Science, KRC College of Horticulture, Arabhavi- 591218, \\ Karnataka, India \\ *Corresponding author
}

\section{Keywords \\ Planting geometry, Dolichos bean, Nitrogen, Phosphorus and Potassium \\ Article Info \\ Accepted: 04 January 2019 Available Online: 10 February 2019}

\begin{abstract}
A B S T R A C T
The field experiment was conducted at experimental plot of Department of Vegetable Science, K R C College of Horticulture, Arabhavi, Belgaum district during Rabi season of 2016-17 and 2017-18 to study the effect of different spacing levels on nutrient uptake and soil fertility status of dolichos bean (Dolichos lablab L.) in medium black soils of Arabhavi". Two year field experiments with seven planting geometry consisting of $60 \times 15$ $\mathrm{cm}, 60 \times 30 \mathrm{~cm}, 45 \times 15 \mathrm{~cm}$ (control), $45 \times 30 \mathrm{~cm}, 45 \times 45 \mathrm{~cm}, 30 \times 15 \mathrm{~cm}$ and $30 \times 30$ $\mathrm{cm}$ were laid out in randomized block design replicated thrice. Data recorded on yield attributes and pod yield were significantly influenced by various plant spacing levels. Wider spacing level $(60 \times 30 \mathrm{~cm})$ significantly increased the number of primary branches, dry matter content, number of pods per plant and pod protein content whereas, narrow spacing levels increased plant height and pod yield per hectare as well as higher total N, P and $\mathrm{K}$ uptake in first (2016-17), second season (2017-18) and even in pooled analysis. The available nutrient status such as $\mathrm{pH}$, Electrical conductivity, organic carbon, $\mathrm{N}, \mathrm{P}$ and $\mathrm{K}$ in soil after harvest was found to be improved due to wider spacing levels during both the growing seasons and most suitable soil $\mathrm{pH}, \mathrm{EC}$ and maximum values of organic carbon were recorded in a spacing of $30 \times 30 \mathrm{~cm}$. However, pooled data analysis revealed that, significantly higher nitrogen, phosphorus and potassium availability per hectare (394.12, 74.80 and $323.01 \mathrm{~kg} / \mathrm{ha}$ ) were recorded in wider spacing $45 \times 45 \mathrm{~cm}$ but it was statistically on par with $60 \times 30 \mathrm{~cm}$ for phosphorus and potassium availability per hectare. The results of two years (2016-17 and 2017-18) experimental data concluded that wider spacing of 30 $\times 30 \mathrm{~cm}$ is optimum planting geometry for cultivation of dolichos bean
\end{abstract}

\section{Introduction}

Dolichos bean (Dolichos lablab L.) is an important leguminous vegetable of India and it is mainly grown for its tender pods and seeds. The crop also used as forage for animals and weed suppressor. It is one of the most ancient crops among the cultivated plants grown as either pure or mixed with other crops. Dolichos bean can be grown in diverse range of environmental conditions due to its wider adaptability and drought 
resistance capacity (Joshi and Rahevar, 2015). Being a legume, it has ability to fix nitrogen into soil thereby improving soil fertility and crop yields in an economic and environment friendly manner. Dolichos bean as a vegetable crop mostly cultivated to a large extent in Karnataka and adjoining districts of Tamil Nadu, Andhra Pradesh and Maharashtra.

Vegetable pod dolichos beans are dense bushy legume crops, therefore, adopting appropriate planting geometry contributes much to a better crop stand and productivity by proper utilization of nutrient source. It is essential to provide optimum plant density per unit area by adjusting the spacing levels. Plants grown in closer spacing exhibit more vertical growth but give less yield and poor quality pods because of insufficient space, light, nutrients and moisture (Dhanraj et al., 2001). Whereas, the plants grown in the wider spacing exhibit more horizontal and continuous vegetative growth due to less population pressure per unit area but, they also give less yield per unit area due to surface runoff and leaching losses of nitrogen and other nutrients in soil (Anilkumar, 2004).

However, plants grown under optimum spacing provide optimum conditions for luxuriant crop growth and better plant canopy by improving soil physico chemical properties thereby produce more pod yield with best quality traits (Mazumder et al., 2007). Hence, the present investigation was carried out with view to study the effect of different spacing levels on nutrient uptake by dolichos bean and physico- chemical properties of soil after crop harvest.

\section{Materials and Methods}

The field experiment was conducted during rabi season of 2016-17 and 2017-18 at experimental plot of Department of Vegetable Science, K R C College of Horticulture,
Arabhavi, Belgaum district. The experiment was laid out in randomized block design with seven treatments replicated thrice. The treatment comprised viz. $\mathrm{T}_{1}-60 \times 15 \mathrm{~cm}, \mathrm{~T}_{2^{-}}$ $60 \times 30 \mathrm{~cm}, \mathrm{~T}_{3}-45 \times 15 \mathrm{~cm}$ (control), $\mathrm{T}_{4}-45 \times$ $30 \mathrm{~cm}, \mathrm{~T}_{5}-45 \times 45 \mathrm{~cm}, \mathrm{~T}_{6}-30 \times 15 \mathrm{~cm}$ and $\mathrm{T}_{7^{-}}$ $30 \times 30 \mathrm{~cm}$.

The recommended spacing level was taken as control. A composite sample of $30 \mathrm{~cm}$ deep soil was used for physical and chemical analysis. The soil of experimental site was medium black soil and the topography of experimental fields was fairly uniform, having $\mathrm{pH}(8.28), \mathrm{EC}(0.78 \mathrm{ds} / \mathrm{m})$, O.M (0.67 $\%)$, available $\mathrm{N}(225.28 \mathrm{~kg} / \mathrm{ha})$, available $\mathrm{P}$ $(65.08 \mathrm{~kg} / \mathrm{ha})$ and $\mathrm{K}(257.07 \mathrm{~kg} / \mathrm{ha})$. The recommended dose of farm yard manure (20 t/ha) and fertilizers (25:50:25 kg NPK/ha) in the form of urea, single super phosphate and muriate of potash, respectively were applied before final harrowing. The required quantities of healthy and disease free authentic seeds of dolichos bean variety 'Arka Amogh' were used for sown. All the recommended package of practices was followed timely during crop growth period (Anon., 2015). Healthy and normal plants were selected randomly and tagged with a label in each plots as per treatment schedule for recording various observations on growth and pod yield parameters. Quality parameters like pod protein content (The total calorimetric method by Lowry et al., 1951) was assessed from the freshly harvested pods. Soil physical and chemical parameters were analyzed by employing the methods such as $\mathrm{pH}$ and EC (Jackson, 1973), organic carbon (Wakley and Black, 1967), available nutrients viz. $\mathrm{N}, \mathrm{P}_{2} \mathrm{O}_{5}$ and $\mathrm{K}_{2} \mathrm{O}$ method given by (Jackson, 1973) and uptake of nutrients (Piper, 1966) in plant pats. Two years experimental data as well as pooled data were analyzed as per the statistical methods i.e. Fisher's method described by Panse and Sukhatme (1978). 


\section{Results and Discussion}

\section{Effect of planting geometry on pod yield of dolichos bean}

Data presented in table 1 revealed that different spacing levels were significantly influenced the growth, yield attributing characters and pod quality in dolichos bean during both the seasons (2016-17 and 201718) of experiment and in pooled data analysis. Growth parameters such as plant height and number of secondary branches were significantly influenced by various plant spacing treatments. Planting geometry plays a significant role in plant height and it was noticed that weak, lanky and significantly more taller plant was produced in case of dense planting whereas reverse trend was noticed in production of primary branches. Significantly the maximum plant height at harvest was $96.80,95.00 \mathrm{~cm}$ and $95.40 \mathrm{~cm}$ recorded when crop was sown at $30 \times 15 \mathrm{~cm}$ $\left(\mathrm{T}_{6}\right)$ during 2016-17 and 2017-18 growing seasons and pooled data respectively. The marked increase in plant height was noticed in narrow spacing which might be attributed to its increased plant population density competition for basic resources such as space, light and plant nutrients compared to wider spacing. Significant differences in production of secondary branches with different plant densities has been observed at different stages of plant growth during first (2016-17), second season (2017-18) and in pooled data. Pooled data analysis revealed that at harvest, the treatment $\mathrm{T}_{2}$ recorded maximum number of secondary branches (7.13) but it was onpar with $\mathrm{T}_{4}$. No particular trend was noticed in production of secondary branches during both the years (2016-17 and 2017-18) of investigation. Significantly maximum number of secondary branches (7.20) obtained in $T_{2}$ as that of pooled data analysis which was followed by $T_{4}$ and $T_{7}$ in 2016-17 growing season. Whereas, in 2017-18, spacing of $45 \times$
$30 \mathrm{~cm} \quad\left(\mathrm{~T}_{4}\right)$ recorded significantly more number of secondary branches (7.10) over other treatments but it was statistically on par with $\mathrm{T}_{2}$. Obviously lesser number of secondary branches was obtained with closer spacing $(30 \times 15 \mathrm{~cm})$ during both the years of investigation (2016-17 and 2017-18) as well as in pooled data. The increase in the number of secondary branches per plant under wider spacing might be due to more space to individual plants for branching and more efficient use of available nutrients, water and light energy which could favour more photosynthesis and allocation of carbohydrate for all growth points. The results are in full agreement with the results recorded by Karigoudar and Angadi (2005), Shrikanth et al., (2008) and Joshi and Rahevar (2015) in dolichos bean. Growth parameters play a vital role in plant biomass production which was increased significantly with decrease in plant population. In the present investigation, owing to the effect of treatments, plant dry matter content $(33.53 \mathrm{~g})$ at final harvest was maximum in dolichos bean spaced at $60 \times 30$ $\mathrm{cm}\left(\mathrm{T}_{2}\right)$ but there is no significance difference found in $\mathrm{T}_{2}$ and $\mathrm{T}_{4}$ treatments. Plant dry matter at final harvest during the year 2016-17 and 2017-18 were followed similar trend as that of pooled data. Shrikanth et al., (2008) also observed significant increase in dry matter production under wider spacing in dolichos bean. The data pertaining to the pod yield was influenced significantly due to various planting geometry followed in dolichos bean and it was increased significantly with higher plant densities in hectare basis when compared to lower plant densities during both the years of study and in pooled data. Therefore, the closer spacing of $30 \times 15 \mathrm{~cm}$ $\left(\mathrm{T}_{6}\right)$ significantly registered more pod yield per hectare (190.34 q) followed by $T_{7}$ and $T_{3}$ whereas, the minimum pod yield was observed in lower plant density accommodated $\mathrm{T}_{5}, \mathrm{~T}_{2}, \mathrm{~T}_{4}$ and $\mathrm{T}_{1}$ during both the years as well as in pooled data. 
Table.1 Growth, pod yield and quality of dolichos bean as influenced by planting geometry

\begin{tabular}{|c|c|c|c|c|c|c|c|c|c|c|c|c|c|c|c|}
\hline \multirow[t]{2}{*}{$\begin{array}{l}\text { Treatment } \\
(\mathrm{cm})\end{array}$} & \multicolumn{3}{|c|}{ Plant height (cm) } & \multicolumn{3}{|c|}{$\begin{array}{c}\text { Number of secondary } \\
\text { branches }\end{array}$} & \multicolumn{3}{|c|}{$\begin{array}{c}\text { Total dry matter (g/ } \\
\text { plant) }\end{array}$} & \multicolumn{3}{|c|}{$\begin{array}{l}\text { Pod yield per hectare } \\
\text { (q) }\end{array}$} & \multicolumn{3}{|c|}{$\begin{array}{l}\text { Protein content (g/ } \\
100 \mathrm{~g})\end{array}$} \\
\hline & 2016-17 & 2017-18 & Pooled & 2016-17 & 2017-18 & Pooled & 2016-17 & 2017-18 & Pooled & 2016-17 & 2017-18 & Pooled & 2016-17 & 2017-18 & Pooled \\
\hline$T_{1}: 60 \times 15$ & 90.33 & 89.13 & 89.73 & 6.20 & 6.13 & 6.17 & 24.87 & 23.53 & 24.20 & 158.49 & 156.56 & 157.53 & 3.16 & 3.10 & 3.13 \\
\hline$T_{2}: 60 \times 30$ & 84.40 & 80.83 & 82.62 & 7.20 & 7.07 & 7.13 & 34.93 & 32.13 & 33.53 & 108.81 & 108.24 & 108.53 & 3.37 & 3.30 & 3.33 \\
\hline$T_{3}: 45 \times 15$ & 91.50 & 90.47 & 90.98 & 6.13 & 6.07 & 6.10 & 22.87 & 19.33 & 21.10 & 167.36 & 163.49 & 165.42 & 3.15 & 3.08 & 3.11 \\
\hline$T_{4}: 45 \times 30$ & 86.70 & 81.93 & 84.32 & 7.07 & 7.10 & 7.05 & 33.47 & 30.90 & 32.18 & 141.31 & 140.74 & 141.02 & 3.30 & 3.26 & 3.28 \\
\hline$T_{5}: 45 \times 45$ & 80.33 & 78.33 & 79.33 & 6.27 & 6.20 & 6.23 & 29.80 & 26.53 & 28.17 & 78.07 & 77.48 & 77.78 & 3.22 & 3.15 & 3.19 \\
\hline$T_{6}: 30 \times 15$ & 96.80 & 94.00 & 95.40 & 5.40 & 5.33 & 5.37 & 19.23 & 17.80 & 18.52 & 190.56 & 190.12 & 190.34 & 3.13 & 3.06 & 3.09 \\
\hline$T_{7}: \mathbf{3 0} \times \mathbf{3 0}$ & 88.53 & 85.27 & 86.90 & 7.00 & 6.47 & 6.77 & 32.17 & 28.70 & 30.43 & 178.59 & 176.08 & 177.33 & 3.26 & 3.19 & 3.22 \\
\hline SE.m \pm & 1.71 & 1.14 & 0.91 & 0.04 & 0.06 & 0.04 & 0.83 & 0.66 & 0.60 & 3.77 & 4.43 & 3.17 & 0.02 & 0.01 & 0.01 \\
\hline CD at $5 \%$ & 5.25 & 3.50 & 2.80 & 0.12 & 0.20 & 0.11 & 2.55 & 2.04 & 1.86 & 11.60 & 13.65 & 9.76 & 0.07 & 0.03 & 0.05 \\
\hline
\end{tabular}

Table.2 Total nitrogen, phosphorus and potassium uptake (kg/ ha) by dolichos bean as influenced by planting geometry

\begin{tabular}{|c|c|c|c|c|c|c|c|c|c|}
\hline \multirow{2}{*}{$\begin{array}{l}\text { Treatment } \\
\text { (cm) }\end{array}$} & \multicolumn{3}{|c|}{ N uptake (kg/ ha) } & \multicolumn{3}{|c|}{ P uptake (kg/ ha) } & \multicolumn{3}{|c|}{ K uptake (kg/ ha) } \\
\hline & 2016-17 & 2017-18 & Pooled & 2016-17 & 2017-18 & Pooled & 2016-17 & 2017-18 & Pooled \\
\hline$T_{1}: 60 \times 15$ & 85.89 & 81.91 & 84.9 & 16.71 & 14.59 & 15.65 & 54.69 & 52.07 & 53.38 \\
\hline$T_{2}: 60 \times 30$ & 73.52 & 68.63 & 72.07 & 12.35 & 10.06 & 11.21 & 47.40 & 43.67 & 45.53 \\
\hline$T_{3}: 45 \times 15$ & 89.13 & 84.51 & 87.82 & 22.68 & 19.48 & 21.08 & 63.57 & 60.14 & 61.85 \\
\hline$T_{4}: 45 \times 30$ & 82.48 & 78.24 & 81.36 & 13.93 & 12.35 & 13.14 & 50.47 & 46.83 & 48.65 \\
\hline$T_{5}: 45 \times 45$ & 63.08 & 57.11 & 60.09 & 9.23 & 8.86 & 9.05 & 44.64 & 41.24 & 42.94 \\
\hline$T_{6}: 30 \times 15$ & 92.05 & 88.75 & 91.40 & 25.05 & 23.69 & 24.37 & 67.24 & 63.30 & 65.27 \\
\hline $\mathrm{T}_{7}: \mathbf{3 0 \times 3 0}$ & 87.04 & 83.48 & 86.26 & 20.54 & 16.09 & 18.31 & 60.86 & 56.07 & 58.47 \\
\hline SE.m \pm & 1.18 & 2.05 & 1.05 & 1.45 & 1.99 & 1.08 & 1.67 & 1.58 & 1.37 \\
\hline $\mathrm{CD}$ at $5 \%$ & 4.71 & 6.33 & 4.24 & 4.45 & 6.14 & 3.33 & 5.15 & 4.88 & 4.21 \\
\hline
\end{tabular}




\section{Int.J.Curr.Microbiol.App.Sci (2019) 8(2): 196-203}

Table.3 Soil fertility status of dolichos bean as influenced by planting geometry

\begin{tabular}{|c|c|c|c|c|c|c|c|c|c|c|c|c|c|c|c|c|c|c|}
\hline \multirow[t]{2}{*}{$\begin{array}{l}\text { Treatment } \\
\quad(\mathrm{cm})\end{array}$} & \multicolumn{3}{|c|}{$\mathbf{p H}$} & \multicolumn{3}{|c|}{$\mathrm{EC}(\mathrm{ds} / \mathrm{m})$} & \multicolumn{3}{|c|}{ OC $(\%)$} & \multicolumn{3}{|c|}{$\begin{array}{c}\text { Available nitrogen } \\
\text { (kg/ ha) }\end{array}$} & \multicolumn{3}{|c|}{$\begin{array}{l}\text { Available phosphorus } \\
\text { (kg/ ha) }\end{array}$} & \multicolumn{3}{|c|}{$\begin{array}{l}\text { Available potassium } \\
\text { (kg/ ha) }\end{array}$} \\
\hline & 2016-17 & 2017-18 & Pooled & 2016-17 & 2017-18 & Pooled & 2016-17 & 2017-18 & Pooled & 2016-17 & 2017-18 & Pooled & 2016-17 & 2017-18 & Pooled & 2016-17 & 2017-18 & Pooled \\
\hline$T_{1}: 60 \times 15$ & 8.40 & 8.51 & 8.45 & 0.80 & 0.35 & 0.58 & 0.70 & 1.22 & 0.96 & 375.51 & 381.25 & 378.38 & 66.22 & 70.67 & 68.44 & 284.58 & 286.27 & 285.42 \\
\hline$T_{2}: 60 \times 30$ & 8.29 & 8.43 & 8.36 & 0.75 & 0.29 & 0.52 & 0.76 & 1.33 & 1.04 & 386.39 & 391.41 & 388.90 & 72.32 & 74.33 & 73.33 & 316.53 & 319.56 & 318.05 \\
\hline$T_{3}: 45 \times 15$ & 8.43 & 8.52 & 8.48 & 0.82 & 0.37 & 0.59 & 0.63 & 1.18 & 0.90 & 373.06 & 377.1 & 375.08 & 63.23 & 66.77 & 65.00 & 280.3 & 283.81 & 282.06 \\
\hline$T_{4}: 45 \times 30$ & 8.33 & 8.43 & 8.38 & 0.76 & 0.34 & 0.55 & 0.76 & 1.27 & 1.01 & 381.06 & 386.67 & 383.87 & 68.82 & 71.11 & 69.47 & 310.55 & 312.53 & 311.54 \\
\hline$T_{5}: 45 \times 45$ & 8.38 & 8.48 & 8.43 & 0.66 & 0.28 & 0.47 & 0.70 & 1.25 & 0.98 & 391.63 & 396.61 & 394.12 & 73.93 & 75.67 & 74.80 & 320.46 & 325.55 & 323.01 \\
\hline$T_{6}: 30 \times 15$ & 8.48 & 8.54 & 8.52 & 0.91 & 0.41 & 0.66 & 0.60 & 1.17 & 0.88 & 368.66 & 372.39 & 370.52 & 61.76 & 64.16 & 62.96 & 262.73 & 264.8 & 263.77 \\
\hline$T_{7}: 30 \times 30$ & 8.00 & 8.17 & 8.12 & 0.73 & 0.28 & 0.51 & 0.72 & 1.29 & 1.01 & 377.82 & 385.4 & 381.61 & 65.63 & 68.92 & 67.28 & 284.6 & 290.94 & 287.77 \\
\hline SE.m \pm & 0.03 & 0.13 & 0.07 & 0.08 & 0.05 & 0.05 & 0.01 & 0.01 & 0.01 & 2.06 & 2.07 & 1.05 & 1.75 & 1.70 & 1.11 & 2.47 & 2.69 & 2.18 \\
\hline $\begin{array}{c}\text { CD at } 5 \\
\%\end{array}$ & 0.20 & NS & 0.21 & NS & NS & 0.14 & 0.04 & 0.04 & 0.02 & 6.36 & 6.37 & 3.24 & 5.40 & 5.24 & 3.41 & 7.62 & 8.28 & 6.71 \\
\hline
\end{tabular}


The observation on pod yield in hectare basis during both the years was followed similar trend as that of pooled data. Similar result was also recorded by Shrikanth et al., (2008) who noticed closer spacing which accommodate more number of individuals per unit area increased pod number per $\mathrm{m}^{2}$ and their cumulative effect on yield resulted in higher yield. It was also noticed that there was significant reduction in pod yield with decrease in plant density but $30 \times 30 \mathrm{~cm}$ recorded more pod yield over $45 \times 15 \mathrm{~cm}$ might be due to increased plant spacing $(30 \times$ $30 \mathrm{~cm}$ ) improved overall performance of plant resulted in highest pod yield per hectare which was quite comparable with the overall pod yield from high planting density accommodated in $30 \times 15 \mathrm{~cm}$.

Quality characters of edible pod such as protein content of fresh green pods of dolichos bean at peak edible stage significantly differed due to spacing levels during both the years of investigation and in pooled data. Significantly maximum protein content $(3.33 \mathrm{~g})$ of fresh green pods was recorded in $T_{2}$ which was significantly superior over other treatments but was on par with $\mathrm{T}_{4}$. In 2016-17 growing season, no significant difference found in $\mathrm{T}_{2}$ and $\mathrm{T}_{4}$ treatments with respect to protein content of fresh pod however, in 2017-18 also, maximum protein content $(3.30 \mathrm{~g})$ of fresh green pods was recorded in $\mathrm{T}_{2}$ followed by $\mathrm{T}_{4}$ and $\mathrm{T}_{7}$.

Significantly, minimum protein content was recorded in higher plant density $30 \times 15 \mathrm{~cm}$ $\left(\mathrm{T}_{6}\right)$ in 2016-17 and 2017-18 growing seasons as well as in pooled data. This might be due to more per cent of nutrient (nitrogen) uptake (nitrogen) by individual plant thereby pods as nitrogen is the structural component of amino acid and protein. These results were also recorded by Joshi and Rahevar (2015) in dolichos bean.

\section{Effect planting geometry on nutrients uptake by dolichos bean}

The observations on nutrient uptake by dolichos bean was studied with respect to nitrogen, phosphorus, potassium uptake at final harvest as influenced by spacing levels during both the years (2016-17 and 2017-18) of investigation and pooled data presented in table 2. The productive capacity of the dolichos bean depends on uptake capacity of major nutrients which helps to exploit higher green biomass, yield and quality parameters. On pooled basis, the total nitrogen, phosphorus and potassium uptake by plant were maximum (91.40, 24.37 and 65.27 $\mathrm{kg} / \mathrm{ha})$ in narrow spacing $30 \times 15 \mathrm{~cm}\left(\mathrm{~T}_{6}\right)$ over rest of the treatments, which was statistically onpar with $T_{3}$. The result findings recorded on plant nitrogen, phosphorus and potassium uptake in 2016-17 and 2017-8 growing seasons followed the same trend as that of pooled data. However, minimum nitrogen uptake was registered with $T_{5}$ treatment $(45 \times 45 \mathrm{~cm})$ during both the experimental years (2016-17 and 2017-18) as well as in pooled data. Nutrients (N, P and K) uptake was significantly higher in narrow spacing due to more number of plants accommodate in narrow spacing but individual nutrient uptake was less due to inter plant competition. These results were also supported the works of Ramanjaneyulu et al., 2018 in cluster bean.

\section{Effect planting geometry on soil fertility status}

The observations on soil analysis which included $\mathrm{pH}, \mathrm{EC}, \mathrm{OC}$, nitrogen, phosphorus, and potassium availability in soil after final harvest as influenced by spacing levels during both the years (2016-17 and 2017-18) of investigation and pooled data presented in table 3. Significantly most acceptable soil $\mathrm{pH}$ (8.00 and 8.12) was recorded under closer 
spacing $30 \times 30 \mathrm{~cm}\left(\mathrm{~T}_{7}\right)$ over rest of the treatments in 2016-17 growing season and in pooled data,. However, soil $\mathrm{pH}$ did not differ significantly during 2017-18 growing season. Similarly, electrical conductivity (EC) of the soil didn't vary among the different planting geometry during both the years of investigation except pooled data analysis. Higher values of EC (0.66) were recorded under $30 \times 15 \mathrm{~cm}\left(\mathrm{~T}_{6}\right)$ but it was on par with rest of the treatments except $T_{5}$ and $T_{7}$ in pooled data. The effect of various spacing levels was found to be non- significant for soil EC during both the years of experiments. This result might be an indication towards its nature which is an inherent properties. Similar observations were also made by Singh et al., (2012) on soil physico-chemical parameters as influenced by planting geometry followed in faba bean cultivation. In contrary to nutrient uptake, the nutrient availability in soil per hectare increased significantly with decrease in the plant density at different stages of plant growth. On pooled basis, significantly maximum available nitrogen $(394.12 \mathrm{~kg} / \mathrm{ha})$ in the soil recorded in the spacing adopted in $\mathrm{T}_{5}(45 \times 45 \mathrm{~cm})$ followed by $\mathrm{T}_{2}$ and $\mathrm{T}_{4}$. Whereas, the findings recorded in 2016-17 and 2017-18 growing seasons for soil nitrogen availability (391.63 and 396.61 $\mathrm{kg} / \mathrm{ha}$ ) was statistically on par with $\mathrm{T}_{2}$. Planting geometry has been found quite effective on phosphorous availability in soil. Pooled data analysis revealed that it was found maximum $(74.80 \mathrm{~kg} / \mathrm{ha})$ in wider spacing $45 \times 45 \mathrm{~cm} \quad\left(\mathrm{~T}_{2}\right)$ which was statistically on par with $\mathrm{T}_{4}$. In first (2016-17) and second (2017-18) season also recorded similar trend as phosphorus availability in soil as that of pooled analysis. Availability of potassium in soil was also significantly influenced by different spacing levels after harvesting of dolichos bean. In pooled analysis, significantly maximum potassium availability in soil (323.01 $\mathrm{kg} / \mathrm{ha})$ was recorded in $60 \times 30 \mathrm{~cm}$ spacing $\left(\mathrm{T}_{2}\right)$ over rest of the treatments except $\mathrm{T}_{4}$. Similar observations on potassium availability of soil also recorded during first and second season growing seasons as that of pooled data. However, minimum soil nitrogen, phosphorus and potassium availability were registered with narrow spacing $(30 \times 15 \mathrm{~cm})$ during both 2016-17 and 2017-18 experimental years as well $\mathrm{s}$ in pooled data. The trend of nitrogen, phosphorus and potassium availability in soil are progressed positively with sparse planting might be due to the nature of each nutrient on soil complex and interaction with dolichos bean roots in rhizosphere or overall uptake was less from soil due to lower plant density in wider spacing compared to closer spacing. Similar results were also reported by Yadav et al., (2014) in cluster bean and Singh et al., (2012) in faba bean.

Therefore, from the two successive growing seasons, it can be concluded that $30 \times 30 \mathrm{~cm}$ was found to be optimum planting geometry for cultivation of dolichos bean which could gave higher pod yield with best quality pod with increased nutrient uptake capacity of dolichos bean by improving physico-chemical properties of soil.

\section{References}

Anilkumar, 2004, Standardization of seed production techniques in fenugreek. M.Sc. (Agri) Thesis, Univ. of Agril. Sci., Dharwad (India).

Anonymous, 2015, Integrated cultivation practices for horticultural crops (Kannada). Univ. Hort. Sci., Bagalkot (Karnataka). pp. 99-100.

Dhanraj, R., Prakash O. M. and Ahlawat, I. P. S., 2001, Response of French bean (Phesolus vulgaris) varieties to plant density and nitrogen application. India. J. Agron., 46: 277-281.

Jackson, M. L., 1973, Soil chemical Analysis, Ed. Prentice Hall of India Pvt. Ltd., 
New Delhi. pp. 121-125.

Joshi, S. K. and Rahevar, H., 2015, Effect of dates of sowing, row spacings and varieties on growth and yield attributes of rabi Indian bean (Dolichos lablab L.). India. J. Agric. Res., 49 (1): 59-64.

Karigoudar, A. S. and Angadi, S. S., 2005, Effect of seed rate, row spacing and fertility levels on growth and yield of field bean for fodder. Karnataka $J$. Agric. Sci., 18 (2): (487-488).

*Lowry, O. H., Rosebrough, N. J., Farr, A. L. and Randall, R. J., 1951, Protein measurement with the Folin phenol reagent. J. Agric., 11 (2): 161-171.

Mazumder, S. N., Moninuzzaman, M., Rahman, S. M. M. and Basak, N. C., 2007, Influence of support systems and spacing on hyacinth bean production in the eastern hilly area of Bangladesh. Leg. Res., 30 (1): 1-9.

Panse, V. G. and Sukhatme, P. V., 1978, Statistical methods for agriculture workers. ICAR, New Delhi.

Piper, C. S., 1966, Soil and plant analysis. Hans publishers, Bombay, 26-28.

Ramanjaneyulu, A. V., Madhavi, A., Neelima, T. L., Naresh, P., Reddy, K. I. and Srinivas, A., 2018, Effect of row spacing and sowing time on seed yield, quality parameters and nutrient uptake of guar (Cymopsis tetragonoloba $\mathrm{L}$. Taub) in semi arid climate of southern Telengana, India. Legume Res., 41 (2): 287-292.

Shrikanth, Merwade, M. N., Channaveerswami, A. S., Tirakannanavar, S., Mallapur, C. P. and Hosamani, R. M., 2008, Effect of spacings and fertilizer levels on crop growth and seed yield in lablab bean (Lablab purpureus L.). Karnataka J. Agric. Sci., 21 (3): 440-443.

Singh, A. K., Bhatt, B. P., Sundaram, P. K., Gupta, A. K. and Singh, D., 2012, Planting geometry to optimize growth and productivity in faba bean (Vicia faba L.) and soil fertility. J. Environ. Bio., 34: 117-122.

Walkely, A. J. and Black, T. A., 1967, Estimation of soil organic carbon by the chromic and titration method. Soil Sci. 37: 29-38.

Yadav, S. K., Patel, A. G. and Yadav, B. L., 2014, Yield, quality and soil fertility of cluster bean (Cyamopsis tetragonoloba L.) as influenced by various row spacing and levels of phosphorus. $A d v$. Res. J. Crop Improv., 5 (2): 101- 104.

\section{How to cite this article:}

Samapika Dalai, Shashikanth Evoor, R. Mulge, A.B. Mastiholi, C.N. Hanchinamani, L. Kukanoor and Kantharaju, V. 2019. Nutrient Uptake and Soil Fertility Status as Influenced by Planting Geometry in Dolichos Bean. Int.J.Curr.Microbiol.App.Sci. 8(02): 196-203. doi: https://doi.org/10.20546/ijcmas.2019.802.024 